\title{
Utilization of Electronic Government in Realizing Transparency and Accountability of Village Government: Synergy of Implementation of Electronic Village Budgeting and Electronic Monitoring System by Banyuwangi Government
}

\author{
Haidar Fikri*; Didik Gunawan Suharto; Rino Ardhian Nugroho \\ Faculty of Social Studies and Politics, Department of Public Administration, Universitas Sebelas Maret, Indonesia \\ Email: haidarfikri@student.uns.ac.id
}

http://dx.doi.org/10.18415/ijmmu.v5i4.425

\begin{abstract}
In this era, technology has influenced several sectors such as education, economy and governance. One of the utilizations of technology in government is the use of electronic governance. Decentralization becomes a way to realize electronic governance. Regional government as a product of decentralization has created innovation from the combination of government management and technology advance. Village is a product of the lowest hierarchical decentralization. Therefore, village has a right to manage government, service, and financial management. The number of fund issued by the central government causes the abuse. Therefore, Banyuwangi government uses technology of electronic governance to conduct innovation in supervising village financial management in order to be accountable and transparent. The innovations are electronic village budgeting and electronic monitoring system. Both applications are utilized well by Banyuwangi government to reach achievement. This research uses descriptive qualitative approach by selecting certain location, Banyuwangi government. The result of the research is an application synergy of electronic village budgeting and electronic monitoring system which becomes the strategy to realize accountability and transparency.
\end{abstract}

Keywords: Electronic Governance (E-Gov); Accountability; Transparency; Village; Electronic Village Budgeting; Electronic Monitoring System

\section{Introduction}

Indonesia has changed the paradigm in holding government system from centralization into decentralization. It causes the open space for hierarchical government to manage their own business based on their characteristics. According to the journey of Indonesian decentralization during 15 years, it shows that Indonesia is on the level of developing state and belongs to the most decentralized state (Shah etc., 2012). According to Litvack \& Seddon, decentralization is "transfer of authority and responsibility for public function from central to sub-ordinate or quasi-independent government organization or the private sector ". The definition of decentralization from Litvack and Seddon is known in the context of government relationship which represents the state and other entities (organization of sub-national government, organization of semi-free government, and private sector. According to Cheema and Rondinelli (1983), if it is seen from the perspective of policy and administration, decentralization is meant 
as; "planning transfer, decision taking, or administrative authority is started from central government to organizations in the field, local administrative units, ...organizations, local government, and nongovernmental organization". According to Hellmut Wollman (2007), decentralization has intrinsic implication of politic to be placed in sub-national agency using its strength, functions and resources.

Indonesia is not separated from the thought of decentralization. The understanding of decentralization is a concept of giving the authority from central government to regional government to manage their own region. Decentralization is aimed to increase efficiency and effectiveness of its service functions in society (Pollitt et al., 1998; Kaplan and Atkinson., 1998; Dillinger and Fay., 1999; World Bank/ International Bank for Reconstruction and Development., 1999). Besides that, decentralization can decrease the risk of political violence such as separatism and ethnic conflict by increasing local autonomy on alocative decision, protecting minority right, improving social service and distributing fiscalresource in the outskirts to solve citizens' complains ((e.g., Brass., 1991; Gurr., 2000; Hechter., 2000; Horowitz., 1991). According to the law no 23 of 2014, Concept of decentralization in Indonesia points three patterns of autonomy, namely autonomy of province, regency and village (Solekhan., 2012; 328). Based on the basis of constitution in managing regional government, village can take a policy to fix the government system based on the social and culture condition and the aspiration of society.

According to the law no 6 of 2014, village or custom village is a unity of law society that has regional limitation to manage its government business and society interest based on their own ideas and origin or traditional right which is recognized and respected in the government system in Indonesia.

According to Haryanto (2007: 2), village has a right to manage their region to be broader. In managing the society interest, village has the authority to; 1) holding government business based on the suggestion right; 2) holding government business that becomes the authority of regency or city to be managed by the village (government business to improve public service; 3) assistance task from government, province government and regency/ city government; 4) other businesses are given to the village.

Decentralization in local village in building the village and empowering the society gives the aspiration that the government puts big effort to improve the society welfare. The progress of the building is also faster. Besides that, it shows that the society is not only the object of the building, but they also become the subjects. Therefore, the giving of authorization to the village government based on the law no 6 of 2014 influences the addition of government'stasks as a realization to fill the needs of society. It affects to the activities that must be paid by the village government. Therefore, the village government needs a fund support to realize the activities such as holding village government, building the village, leading and empowerin the society, conducting village establishment and improving infrastructures such as bridge, road, irrigation, health centre and etc. The problems above is appropriate with the law no 6 of 2014 about village. The central government distributes the fund such as allocation of village fund an village fund.

The emergence of village fund policy is a realization of village right fulfillment to hold its autonomy to grow and develop. It is also as the fulfillment of village needs related to the implementation of village government and the improvement of society capacity such as leading and empowering society and providing adequate infrastructures.

Village is not supposed to be a government system that relies on the central government. Village is a unity of law society. It can realize all rights, duties and authorities in government system. It also manages all the needs based on the law. It encourages the government administration to continuously develop its system to follow the dynamism of changes. It is also expected to be able in managing and holding the government according to the aspiration of society. 
Based on the law no 6 of 2014 paragraph 18, each village has an authority to hold the village government, conduct village establishment, lead and empower the society according to the origin and custom right. Village fund is all rights and duties that can be valued with money and stuff. Rights and duties might be income, shopping, funding and financial management. According to the regulation of ministry of foreign affair (No 113 of 2014) about the management of village fund, the definition of management of village fund is all activities of planning, implementation, management, report and responsibility of village fund. In paragraph 2, it explains that village fund must be managed with transparency, accountability and participation. It must also be conducted with orderliness and disciplinary. The implementation of village fund management with transparency, accountability and participation is the realization of good governance in village level.

The importance of accountability in the implementation of village government is written in the law no 6 of 2016 in paragraph 24. It states that the implementation of village government is based on several principles such as: law certainty, orderliness of government implementation, orderliness of general interest, openness, proportion, professionalism, accountability, effectiveness and efficiency, local wisdom, diversity, and participation.

Village chief as village government has a task to implement village government, conduct village establishment, lead and empower society. Therefore, village chief has several tasks such as managing the fund and assets according to its principles written in law regulation. It is also written in the regulation of ministry of foreign affair of Indonesia no 113 of 2014 about the village fund;

(1) Village fund is managed based on the principles of transparency, accountability, and participation and it is conducted through orderliness and estimation disciplinary.

(2) In paragraph 1, the management of village fund is managed for 1 year which is started from the first of January untill the 31st of December.

The implementation of village fund program has been conducted in 2015. Based on the president regulation no 36 of 2015 in attachment XXII about the detail of village fund in 2015 in regency/ city, the number of calculation allocation for village fund was 20,77 trillion. In 2016, it increased into 46, 98 trillion (president regulation no 137 of 2015 in attachment VII about the detail of village fund in 2016 in regency/ city). In 2017, the fund allocation was 60 trillion. In 2018, it reached 80 trillion (news.detik.com). The big amount of fund needs a planning system to use the village fund itself. Village government needs to manage it well.

It needs big responsibility in managing the village fund because it might create potential of problems for Indonesian government, such as corruption. Table 1 shows the data.

Based on Table 1, corruption happens in village government which emerges many losses for the state. The type of corruption can be embezzlement, budgeting and authority abuse, illegal charges, budgeting mark up, fictitious report, budget cutting and bribery (news.detik.com). There are five signs of corruption in the management of village fund such as planning process, responsibility process, monitoring and evaluation, implementation, and provision of things and service in distributing and managing village fund (news.detik.com). 
Table 1 The abuse of village fund management

\begin{tabular}{|c|c|c|c|}
\hline No & Findings & Source & Type of findings \\
\hline 1 & $\begin{array}{l}\text { According Indonesia Corruption Watch } \\
\text { (ICW), there were } 110 \text { cases of } \\
\text { corruption of village fund in } 2016 \text { untill } \\
10 \text { August } 2017 \text {. }\end{array}$ & (news.detik.com). & Finding of NGO \\
\hline 2 & $\begin{array}{l}\text { State minister for acceleration } \\
\text { development backward regions through } \\
\text { task force has accepted } 10.000 \\
\text { complaining reports from the society } \\
\text { since October 2017. The number of } \\
\text { reports has increased in which there are } \\
900 \text { reports in previous year. }\end{array}$ & (nasional.sindonews.com). & $\begin{array}{l}\text { Finding of executive } \\
\text { (village task force) }\end{array}$ \\
\hline 3 & $\begin{array}{l}\text { Based on the data of police force in } \\
2012-2017 \text {, there are several abuses of } \\
\text { village fund. It is almost } 214 \text { cases that } \\
\text { involve the calculation of } 46 \text { billion. }\end{array}$ & (netralnews.com) & Finding of police force \\
\hline 4 & $\begin{array}{l}\text { The increase of deviation has been } \\
\text { conducted by the village chief and } \\
\text { village officials. There are } 110 \text { cases } \\
\text { which involve the village chief. Besides } \\
\text { that, the perpetrators of corruption are } \\
30 \text { village officials and the wives of } \\
\text { village chief ( } 2 \text { persons) }\end{array}$ & (news.detik.com). & NGO \\
\hline
\end{tabular}

Source: data was processed by the researchers from several sources (2018)

There are many cases in the village as shown at Table 1 . Therefore, village is demanded to be able in managing village fund with accountability. In this research, the researcher selects Banyuwangi regency because it uses electronic village budgeting in managing the village fund. Banyuwangi is the only area in Indonesia which uses the system of information technology. Mr. Tri as the leader of management of social institution in agency of society and village empowerment in Banyuwangi regency states that:

"when everyone hears E-village budgeting, they are amazed that Banyuwangi has used online system. The government also creates its own system." (interview conducted in May, 25 2018)"

Banyuwangi regency is one of regional governments that conducts innovation in public sector to repair its service and increase regional competition. Banyuwangi regency utilizes system information technology in conducting the regional innovation (Ratih., 2016). The use of system information technology (SIT) has important role to develop government organization (Iswahyudi., 2017). The use of SIT in organization will help the task to be more effective in achieving the purposes of organization. The use of SIT in government has been started since the launching of president instruction no 3 of 2003 about the policy and national strategy in developing Indonesian e-government. The instruction contains the utilization of communication and information in government process (electronic government) which can improve efficiency, effectiveness, transparency and accountability of government implementation. $E$ government or e-gov is the use of information technology to give information and service to the society with efficiency and accountability (Kesuma., 2012). Concept of e-government is that the society can interact with service posts, talk by phone to have government service, and send the letter to the 
government (Sosiawan., 2008). E-government is based on its functions. It is the use of information technology that can connect between the government and society in public service.

Banyuwangi government uses technology in government as the main pillar to support public service in Banyuwangi (start from regional to village government (Iswahyudi., 2017). The first step is conducting cooperation with PT. Telkom to install 1.000 points of free wifi in the whole areas of Banyuwangi regency. Innovation of public service as the program of Banyuwangi regency is; smart village program, transparency of regional financial budgeting management, system of government work accountability, and E-village budgeting (banyuwangikab.go.id).

One of the strategies issued by Banyuwangi government to realize good and clean government in village government level is creating innovation program of Electronic Village Budgeting (EVB). Evillage budgeting is a budgeting system of village government which is integrated in a network or online system in Banyuwangi (Ratih., 2016). E-village budgeting is one of the innovation examples to realize budget transparency and establishment monitoring in the village. This system is implemented in 189 villages in Banyuwangi regency (banyuwangikab.go.id).

Besides electronic village budgeting (EVB), Banyuwangi regency has another information system namely electronic monitoring system. Both systems become the strategy of Banyuwangi regency in realizing transparent and clean government. This researsch has main question; how is the strategy of Banyuwangi government in synergizing both systems of electronic governance to realize a clean and transparent village government?.

\section{E-Gov}

Adoption of information technology or e-government is an absolute thing. E-government is meant as the use of computers and the internet by government of information and communication technologies to deliver information and services to citizens, businesses, and other stakeholders (Nam., 2014). The definition of e-government has a meaning as the use of information technology media by the government in delivering information and implementing service to the society, business and several related sides. Therefore, e-government has two functions as information flows and service processes.

Wang and Liao (2008) state that many governments realized the importance of using information and communication technologies to provide efficient and transparent government.Prybutok, Zhang, and Ryan (2008) state that technology helps governments to improve services and assists inbuilding trust between governments and businesses, and between government employees and the general public.

Adoption of information technology in government and the use of e-government give several advantages for the government in implementing service, delivering information to public and building the trust to public and business. Through e-government, it helps the government to implement effective, efficient and opened government which can be responsible to the public. E-government gives a media to the public to supervise several activities to lose the mistrust on the government implementation.

Yildiz (2007) states that E-government has emerged as a popular catchphrase in public administration to cover functional areas such as service delivery, interactivity, decentralization, transparency, and accountability. Larsson and Gronlund (2014) delivers that technology plays a central part in the development of the public sector; it can act both as an enabler and as an obstacle to sustainability. United Nation (2014) states that implementation of e-government systems and appropriate applications require acquisition of new skills from the government employees. 
E-government as a renewal in implementing the governance gives several advantages. In another word, the use of e-government has several troubles. One of them is the duty to improve the skill of $e$ government management for the government employees.

Related to the type of services in e-government, Indrajit (2004: 30) divides the type of services into three main classes namely publish, interact, and transact as shown in Table 2.

Table 2 Type of services

\begin{tabular}{cll}
\hline No. Type of services & \multicolumn{1}{c}{ Explanation } \\
\hline 1 Publish & This type is the easiest implementation of e-government because the project \\
& is small scale. Most of the applications do not need to involve big and \\
& various resources. Based on this publish clas, the communication is one \\
& direction. It means that the government publishes any data and informations \\
& to be accessed by the public and other sides freely and directly through the \\
& internet. \\
& In interact, there is two direction communications between government and \\
& related sides. Two types of application which is usually used is portal type. \\
& The site gives searching facility for everyone who wants to search for \\
& spesific data and information (in publisher class, the users can only follow \\
& it). Second application is channel in which the public can discuss with the \\
& related units directly (chatting, tele-conference, web-TV) and indirectly \\
& (email, frequent ask questions, newsletter, mailing list).
\end{tabular}

3 Transact Process in this class is two direction interactions like in interact class. The difference is that the transaction relates with the money movement from one side to another side (It is not free because the public must pay upon the service given by the government or partners)

Source: Indrajit (2004)

E-budgeting is a system of budgeting arrangement which belongs to computer program application of web to facilitate the process of budgeting arrangement. E-budgeting can be applie in regional and village government. Based on the explanation above, Banyuwangi regency conducts transformation related to the management of village fund using e-budgeting (electronic village budgeting). It relates with the agency of society and village empowerment. There are several features in $e$ budgeting such as the making of composer components in the use of budgeting.

a. Header frame; It contains the user name application of institution and information of users' identity.

b. Navigation frame; It contains available menu in an application.

c. Content frame; It is the content display of menu in navigation frame.

\section{Accountability and Transparency of Government}

Akbar (2012) states that accountability can be literally defined as a responsibility. According to the simple interpretation, the definition of accountability can be unclear if it is related to the definition of accounting and management. Furthermore, according to Stewart, the concept of accountability on the 
level of accountability itself consists of 5 levels, such as: 1) accountability for probity and legality; 2) process acountability; 3) performance accountability; 4) programme accountability; dan 5) policy accountability.

Accountability can be defined as a kind of duty as a responsibility of success and failure in implementing mission of organization to achieve the purposes through the responsibility media in period (Stanbury., 2003 in Ismiarti., 2013: 30). Basically, accountability is giving information and disclosure on the activities and financial work to the related sides (Schiavo-Campo and Tomasi., 1999 in Mardiasmo, 2006: 4). Central and regional government must be the subject of information giver in fulfilling public rights (right to know, right to get information and right to be listened its aspirations). Annisaningrum (2010: 1) states that accountability is the responsibility to manage resources and policy implementation which is trusted to the report entities in achieving the periodical purposes. Accountability is a duty to deliver the responsibility and answer the work and action of somebody/ law agency/ collective leader in organization to the sides that have rights and authorities. Criteria of financial accountability is as follows; 1) the responsibility of public fund; 2) the presentation is on time; and 3) the audit or response of government. Principle of public accountability is the measurement to show the level of service implementation suitability and the values or external norms owned by the stakeholders who have the interests with the service (Krina., 2003 in Rahmanurrasjid., 2008: 85-86).

Accountability is the behavior and characteristic of human life that can be seen from 2 sides, such as; a) internal accountability of somebody; and b) external accountability of somebody. According to internal side, accountability is the responsibility to the God. Accountability is the responsibility to everything that has been done. It is only known and understood by themselves. Therefore, internal accountability is known as spiritual accountability. External accountability is the accountability to the environment (formal and society environment). The failure in filling external accountability is wasting time, fund and government resources, public authority and trust to the government. External accountability is easily measured because the norms and standards have been clear. External control and values have existed in the system and procedure of work. An employer will supervise their employees and give the warning to the mistakes.

Mahmudi in Istiqomah (2015: 12) explains that financial accountability is very important because the management of public fund will be the main attention for the society. Accountability shows the relationship between authority and control through the responsibility (reports/ notes). Mahmudi in Istiqomah (2015: 12) states that public accountability is divided into two:

a. Vertical accountability is the accountability to the higher authority.

b. Horizontal accountability is the accountability to the public and society to other institutions which have no relationship. Horizontal accountability can also be conducted to legislative institution in which the position is as the public representatives.

The appropriate accountability in this research is vertical and horizontal accountability. It is because the accountability conducted by the village government in managing village fund through electronic village budgeting is the accountability to the higher authority (vertical accountability). However, horizontal accountability can not be ignored.

Public accountability and openness can not be separated from the principles of good governance. The implications become the most discussed topic and interchangable. The implementation is on the pattern of planning, implementation, and responsibility of participative regional finance as logical consequence (Akbar., 2012: 2). The concept of accountability in Indonesia is not a new thing. Most of 
government institutions emphasizes the concept of accountability in implementing the functions of government administration.

Besides accountability, one of actualization values and principles of good governance is that apparatus transparency and public management system must develop the system of openness and accountability. The ultimate goals of good governance is the realization of a professional, legal, transparent, accountable, credible, clean, sensitive and responsive government to all ethical interests and aspirations, the spirit of service, and public accountability and service integrity in carrying out the mission of the nation's struggle to realize the goals and goals of the state.

Transparency means the government openness in giving information related to the activity of the public resource management activities to the sides that need information (Mardiasmo., 2010: 30). Transparency means that the public has the same rights and accesses to know the budgeting process because it relates with the aspirations and interests of society especially on the fulfillment of living needs. Coryanata (2007) states that transparency is made upon the free basis of information flows, all government processes, and institution and information need to be accessed by the concerning sides. The information must be adequate and easily understood and supervised. The budgeting arranged by the executive sides can be transparent if it fulfills the criterias as follows: 1) the announcement of budgeting policy; 2) the budgeting document which is easily accessed; 3) the punctual responsibility report; 4) the accomodation of public aspirations; and 5) the system of information issue to the public. According to Annisaningrum (2010: 2), transparency is giving opened and honest financial information based on the consideration that the society has a right to know the government responsibility in managing resources which is trusted to them on the law regulation. The implementation of transparent government will have the criterias as follows: opened responsibility, access of financial report, publication of financial report, rights to know the audit result and the suitability of working information.

According to Werimon, et.al (2007: 8), the principle of transparency consists of two aspects such as public communication by the government and public rights towards the information access. The government is expected to build broader communication with the society related to several aspects in the context of building. The publics have a right to know everything conducted by the government. Werimon (2007: 8) states that there are 4 components of conceptual planning in building the transparency of public sector organization; 1) the system of financial report; 2) the system of working measurement; 3) auditing public sector; 4) the functions of public accountability channel.

Furthermore, the budget arranged by the executive sides can be transparent if it follows several criterias; 1) the announcement of budgeting policy; 2) the budgeting document which is easily accessed; 3) the punctual responsibility report; 4) the accomodation of public aspirations; 5) the system of information issue to the public. If the public policy (state budget) is more transparent, the supervision conducted by the council will increase because the public does the supervision.

According to Krina (2003) in Rahmanurrasjid (2008: 87-88), transparency principle can be measured through these several indicators such as; 1) mechanism ensures the system of openness and standarization of public service processes; 2) mechanism facilitates public questions about policies, public service and public sector processes; 3) mechanism facilitates the report, information distribution, and action deviation of public apparatus in conducting the service.

\section{Methodology}

This research belonged to descriptive research using qualitative approach. Strauss and Corbin (2003: 4) states that descriptive research results the findings that can not be obtained using statistic 
procedures or other quantitative ways. Descriptive method using qualitative approach is conducted through reading, elaborating, and interpreting to create a conclusion in a systematic writing.

Focus of the research was the synergy of financial management through the innovation of Electronic Village Budgeting and Electonicmonitoring system. The location of the research was conducted in Banyuwangi regency. The site of the research was the agency of society and village empowerment in Banyuwangi regency. Technique of collecting data was conducted through observation, interview and documentation. The research instruments were the researcher, field note, and interview guide. Data analysis used interactive model analysis. According to Miles and Huberman (1992: 16-20), interactive model analysis is collecting, reducing, and presenting the data and creating conclusion.

\section{Discussion}

\section{The Implementation of Electronic Village Budgeting as the Supervision of Village Financial Management}

To support the growth of the society welfare as well as to achieve progress or improvement of village development in the future to be more quickly and efficiently, it is demanded for the provision of village development budget in large quantities. In 2015-2016, village fund had been issued from the state budget. Banyuwangi was one of the regencies that obtained the fund from the central government. Therefore, it needs the optimalization of utilization. Village fund through planning, management, report and accountability becomes the essential part to be conducted by the village government. Transparency and accountability are the ways to avoid illegal utilization and problems in the future.

The burden of authority and responsibility of the village government in real terms is increasing especially in the field of village financial management because all village expenditures are entirely handled by the village government. Therefore, the readiness of human resources and professional behavior of the village apparatus will influence the work of the village government. The phenomenon of corruption, collusion and nepotism in several regions becomes stronger due to the local political hegemony. Therefore, it needs a transformation of technology information that can guide all sides to be more transparent. The innovation is created through Electronic Government (E-Gov).

In building the region, Banyuwangi government implements technology and information system to support the government implementation and public service. Therefore, Banyuwangi government implements digital society to reach information needs for the society. Electronic government is also applied to accelerate the information accomplishment and public service and to supervise the government work.

In managing village fund in Banyuwangi regency, the government conducts transformation using internet and e-government called Electronic Village Budgeting (E-VB). Application program of Electronic Village Budgeting (E-VB) is the program to manage village fund based on the regent regulation no 15 of 2015 about the guidance of village fund management in Banyuwangi regency. It is stated that the definition of Electronic Village Budgeting is the application system of information technology about the village fund provided by the regency government which is used as a media of budgeting, management and report.

The implementation of Electronic Village Budgeting (E-VB) is developed using web (internet). Therefore, it is easily applied in Banyuwangi regency because the region has had the internet network. This application is developed using the concept of open sources and open platform to increase the independence of Banyuwangi regency in managing the application. The configuration of the application is 
as follows; Operating System (OS) of GNU Linux or Ms Windows 2000/2003/XP, Apache Webserver version 1.3 and above, PHP version 5 and above, mySQL version 5 and above. The application is developed through web. If the user wants to login to the application, it will be directed to web browser to the address of (http://e-VillageBudgeting.banyuwangikab.go.id/) that has been created by the administrator. There are several web browser that can be used such as Ms Internet Exlorer, Netscape or Mozilla. If the address is correct and all standards are filled, the display will be as Fig 1.

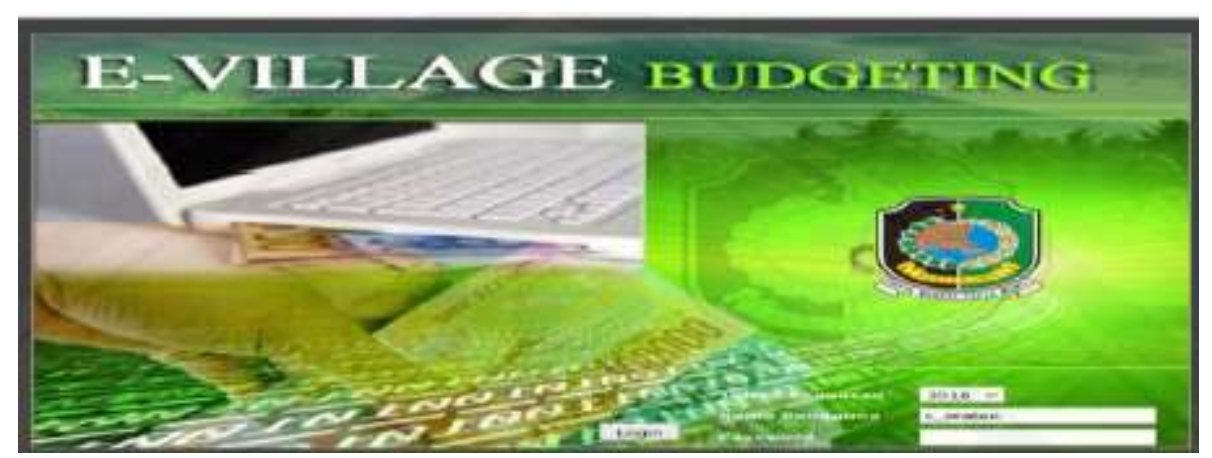

Source: EVB. Banyuwangi

Fig. 1 Initial login of Electronic Village Budgeting application

To login into the application, fill the username and password and press the button. If the name and password are correct, go to the application of Electronic Village Budgeting. Below is several groups of system application users based on the tasks and authorities.

1. Administrator group: a group for application administrator. The authorities of group administrator are all available features, users' registration and other application managements.

2. Executive group: group of decision takers (executive/ managerial) that relates to the data of summary or aggregates of data combination required by the decision takers (executive). Data is presented in recapitulation or graphic.

3. Work and budgeting operator group: group which fills financial report to E-village budgeting from the related sides. Concerning with brief fulfillment manual on the application page of Electronic Village Budgeting, there are several menu such as;

\section{a. Planning menu consists of;}

$>$ Working planning of village fund manager contains working planning of village fund manager activities.

$>$ Validation of working planning of village fund manager

$>$ Working planning and village budgeting; it contains income, acceptance, outcome, indirect and direct expenditures, working planning and village budgeting validation.

$>$ Report (recapitulation): attachments of regional budgeting. 


\section{b. Administration menu consists of;}

$>$ Regional budgeting. It consists of the validation of regional budgeting, financial officials, bank account.

Budgeting implementation document. It consists of data import of working planning and budgeting, budgeting implementation document, activity technical officer (PPTK), income, document of receipt and expenditure, direct expenditure of village, ratification of village budget implementation document.

Village expenditure. It consists of fund provision letter, payment request letter (SPP), payment order letter (SPM).

Village fund management through electronic village budgeting is conducted by village government (the treasurer as the operator). Village secretary is as the technical organization coordinator. Village chief is responsible for the management of village fund. Figure 2 shows village fund management through electronic village budgeting.

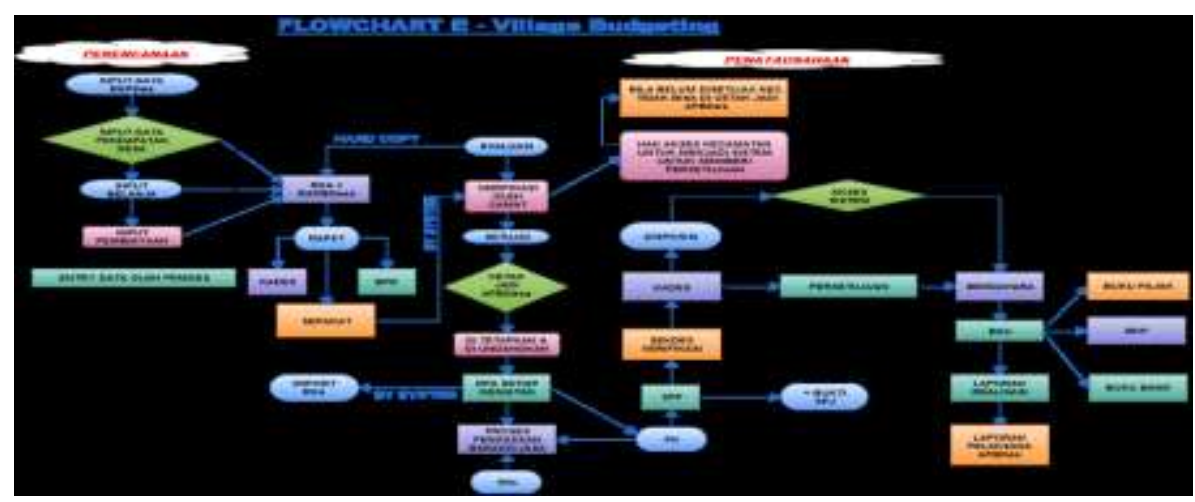

Fig. 2 Flowchart of electronic village budgeting

Based on the explanation of the chart above, the initial step in village fund management relates with the working planning of village fund management. It consists of data input of village income, expenditures, and payment (working and budget planning and village budget planning).

Table 3 Indicators of village fund management through electronic village budgeting

\begin{tabular}{lll}
\hline Type of indicators & \multicolumn{1}{c}{ Hard copy } & Through the system of $E-V B$ \\
\hline $\begin{array}{l}\text { Fund and budgeting } \\
\text { planning }\end{array}$ & $\begin{array}{l}\text { Draft of working and budgeting } \\
\text { planning }\end{array}$ & $\begin{array}{l}\text { Document of budgeting } \\
\text { implementation. Activity (import of } \\
\text { RKA) }\end{array}$ \\
\hline Budgeting planning & Detail of village budgeting & $\begin{array}{l}\text { Administration of responsibility } \\
\text { letter and payment request letter }\end{array}$ \\
\hline
\end{tabular}




\section{The Role of Electronic Monitoring System in Building Supervision}

E-village budgeting $(E-V B)$ is the system of village fund which is same as the information system of regional fund management in regency/ city. However, it directly connects with the agency of regency building planning. $E-V B$ consists of three parts such as planning, management, and evaluation and all online systems.

E-village monitoring (EVM) has a function to supervise the building program in the village (physic and non-physic). Anas states that after being counted, there are more than 4.000 programs in 189 villages in Banyuwangi regency. There are at least 3 visitations to supervise physical program. Therefore, it needs 12.000 visitations of supervision (www.jpnn.com). The finding of EMS is really helpful because it does not need to do many visitations. It has been assisted by the application.

\section{Synergy of E-village Budgeting and E-monitoring System in Realizing Accountability and Transparency of Village Government}

Village has become the attention in each region. Village is a kind of the lowest decentralization in public administration. In the concept of decentralization in the law no 23 of 2014 about regional government, it points three patterns of autonomy such as province, regency and village autonomy (Solekhan., 2012;328). Village as the region that belongs to the category of decentralization encourages the village government to be able in managing its governance according to its purposes. Decentralization is aimed to increase the government's efficiency, effectiveness and service functions to the society (Pollitt et al., 1998; Kaplan and Atkinson., 1998; Dillinger and Fay., 1999; World Bank/ International Bank for Reconstruction and Development., 1999).

Indonesia has many cultures which makes the village have their own characteristic. Each region has its own uniqueness. Village has a right to manage policy, service and administration. According to Haryanto (2007: 2), village has a right to manage its area more broadly. In managing the society interest, village has the authorities such as 1) implement the government's business based on the suggestion right; 2) implement the government's business that becomes the authority of regency/ city. The management is authorized to the village. The business can directly increase the public service; 3) assistance task from the government, province government and regency government; 4) another government business. Haryanto states that in managing village rights, the central government gives special fund to the village. Therefore, village government becomes the main attention because it receives much money and must be managed by itself.

The implementation of village fund program has been conducted in 2015. Based on the president regulation no 36 of 2015 in attachment XXII about the detail of village fund in 2015 in regency/ city, the number of calculation allocation for village fund was 20,77 trillion. In 2016, it increased into 46, 98 trillion (president regulation no 137 of 2015 in attachment VII about the detail of village fund in 2016 in regency/ city). In 2017, the fund allocation was 60 trillion. In 2018, it reached 80 trillion (news.detik.com). The big amount of fund emerges the problems related to transparency and accountability. The problems can be detected from the cases of village chief and apparatus that abuse the fund. The type of abuse can be seen at Table 1. Due to the cases, Banyuwangi as the largest regency in East Java has a new strategy.

The advance of technology is utilized by the government in conducting the governance. Information technology in government management is called as electronic governance. Yildiz (2007) states that E-government has emerged as a popular catchphrase in public administration to cover functional areas such as service delivery, interactivity, decentralization, transparency, and 
accountability. Larsson and Gronlund (2014) also delivers that technology plays a central part in the development of the public sector; it can act both as an enabler and as an obstacle to sustainability. Based on the statements above, Banyuwangi goverment uses technology as a strategy to solve the abuse of village fund management. In another word, Banyuwangi government wants to create a village fund management with accountability and transparency.

The utilization of information technology in Banyuwangi regency in village fund management is electronic village budgeting and electronic monitoring system. Application program of Electronic Village Budgeting (E-VB) is the program to manage village fund based on the regent regulation no 15 of 2015 about the guidance of village fund management in Banyuwangi regency. It is stated that the definition of Electronic Village Budgeting is the application system of information technology about the village fund provided by the regency government which is used as a media of budgeting, management and report. $E$ village monitoring (EVM) has a function to supervise the building program in the village (physic and nonphysic). Anas states that after being counted, there are more than 4.000 programs in 189 villages in Banyuwangi regency. There are at least 3 visitations to supervise physical program. Therefore, it needs 12.000 visitations of supervision (www.jpnn.com).

The online application of village fund management is aimed to increase transparency and accountability. This application consists of three parts such as planning, management and evaluation based on online system. This system removes the manual system in budgeting arrangement in village level. Through this way, the fund can also be supervised. Banyuwangi is one of the largest regions in East Java with 24 subdistricts and 189 villages. Through this application, control of village fund utilization can be conducted everytime without visiting each village. This system is aimed to give protection for village officers to use the fund more effectively.

This system removes the manual system in budgeting management in village level. Through this way, the fund issue can be easily supervised. If the fund is issued, it will be synchronized. The activities are also arranged well based on the planning and budgeting. If the program has not finished, the fund can not be issued. It can avoid the abuse and give protection to the village officers.

E-village monitoring (EVM) is functioned to supervise the building program in the vilage (physic and non-physic). Anas states that after being counted, there are more than 4.000 programs in 189 villages in Banyuwangi regency. There are at least 3 visitations to supervise physical program. Therefore, it needs 12.000 visitations of supervision. Those visitations must not be effective and efficient. EVM will be helpful because it uses online system. The subdistrict sides will take the pictures of program implementation. For example, the officer will take the process of road establishment (from 0\% till 100\% or before and after the establishment). Physical program will be supervised through IT system based on the feature of google map. Therefore, the condition of the road can be seen by the public, especially to the related sides who supervise the project. It is aimed to avoid and minimize the abuse.

Both applications have filled the accountability and transparency. According to Werimon, et. al (2007: 8), the principle of transparency consists of two aspects such as public communication by the government and public rights towards the information access. The government is expected to build broader communication with the society related to several aspects in the context of building. The public have a right to know everything conducted by the government. Werimon (2007: 8) states that there are 4 components of conceptual planning in building the transparency of public sector organization; 1) the system of financial report; 2) the system of working measurement; 3) auditing public sector; 4) the functions of public accountability channel. Furthermore, the budget arranged by the executive sides can be transparent if it follows several criterias; 1) the announcement of budgeting policy; 2) the budgeting document which is easily accessed; 3) the punctual responsibility report; 4) the accomodation of public aspirations; 5) the system of information issue to the public. If the public policy (state budget) is more

Utilization of Electronic Government in Realizing Transparency and Accountability of Village Government: Synergy of Implementation of

Electronic Village Budgeting and Electronic Monitoring System by Banyuwangi Government 
transparent, the supervision conducted by the council will increase because the public does the supervision. Accountability shows the relationship between authority and control through the responsibility (reports/ notes). Mahmudi in Istiqomah (2015: 12) states that public accountability is divided into two:

a. Vertical accountability is the accountability to the higher authority.

b. Horizontal accountability is the accountability to the public and society to other institutions which have no relationship. Horizontal accountability can also be conducted to legislative institution in which the position is as the public representatives.

Upon both applications of village fund management, Banyuwangi regency has an achievement as TOP innovation 99 of 2017 by the state minister for the empowerment of state apparaturs. Both programs developed by the government has been chosen again as 99 of the best innovation in the innovation competition of public service held by the state minister for the empowerment of state apparaturs and bureaucracy reformation (kompas.com). Besides that, EVB obtains the achievement as TOP 40 in the innovation competition of public service held by the state minister for the empowerment of state apparaturs and bureaucracy reformation (news.detik.com).

\section{Conclusion}

Village is another type of decentralization in Indonesia. Village government has their own right to manage the governance, administration and service. Therefore, the central government gives the fund to support the establishment, service and management of village. The amount of fund is increasing year by year. It needs tighter supervision. The number of villages in Indonesia and the less supervision cause the abuse which is conducted by several leaders and officers.

Banyuwangi regency is the largest regency in East Java. There are 189 villages in Banyuwangi regency. The broad area and village ownership encourage the regency to create an innovation. The utilization of information technology in government management creates an application which is called as electronic village budgeting (EVB) and electronic monitoring system (EMS). Both applications are aimed to supervise and manage the village fund in Banyuwangi regency.

The synergy of both applications becomes a new innovation in village fund management with accountability and transparency. The use of the application makes the government easy to manage the village fund. The applications also create achievement. The government obtains the achievement as 99 TOP innovation and 40 innovation issued by the state minister for the empowerment of state apparaturs and bureaucracy reformation. Therefore, Banyuwangi government becomes the pilot project of state minister for the empowerment of state apparaturs. It will also direct the regency to be "smart village"

\section{References}

Akbar, B. (2012). Akuntabilitas Publik dan Peran Akuntansi Keuangan Daerah Pada Pemerintah Daerah. Artikel. Fordfoundation. Public Interest Research and Advocacy Center. Hal 1-2.

Annisaningrum. (2010). Akuntabilitas dan Transparansi Dalam Laporan Keuangan. (Online). (diakses 14 Mei 2018) tersedia di World Wide Web: http://ovy19.wordpress.com. 
Anselm. Strauss, Corbin. Juliet. (2003). Dasar Dasar Penelitian Kualitatif. Yogyakarta: Pustaka Pelajar.

Brass, P. R. (1991). Ethnicity and Nationalism: Theory and Comparison. Sage Publications.

Cheema, G. S and Rondinelli. G. A (editors) 1983: Decentralization and Development: Policy Implementation in Develoing Countries, Beverly Hills, Sage.

Coryanata, Isma. (2007). Akuntabilitas, Partisipasi Masyarakat, dan Transparansi Kebijakan Publik Sebagai Pemoderating Hubungan Pengetahuan Dewan Tentang Anggaran dan Pengawasan Keuangan Daerah (APBD). Makalah disajikan pada Simposium Nasional Akuntansi X. Unhas.Makasar.

Dillinger, W. and Fay, M. (1999). "From Centralized to Decentralized Governance", Finance and Development, International Monetary Fund, 36: 1.

Gurr, T. (2000). Peoples Versus States: Minorities at Risk in the New Century. U.S. Institute of Peace Press.

Haryanto, Tri. (2007). Menuju Mayarakat Swadaya dan Swakelola. Klaten: Cempaka Putih.

Hechter, M. (2000). Containing Nationalism. Oxford University Press.

Horowitz, D. (1991). A democratic South Africa? Constitutional Engineering in a Divided Society. University of California Press.

Indrajit, Richardus Eko. (2004). Kajian Strategis Cost Benefit Teknologi Informasi. Andi. Yogyakarta.

Ismiarti. (2013). Analisis Inplementasi Sistem Pengendalian Intern Pemerintah, Akuntabilitas dan Transparansi Terhadap Kinerja Pemerintah. Tesis. Bengkulu. Program Magister Akuntansi FE Unib.

Jennie Litvack, Junaidi Achmad, and Richard Bird. (1999). Rethinking Decentralization in Developing Countries, The World Bank Washington D.C, USA.

Kaplan, R. S. and Atkinson, A. A. (1998). Advanced Management Accounting, 3rd ed., Prentice-Hall, Englewood Cliffs, NJ.

Kesuma, I Made Gde Partha. (2012). E-Government Dalam Transparansi Sistem Pemerintahan Modern. Diakses melalui http://www.biropem.baliprov.go.id /id/E-Government-Dalam-Transparansi--SistemPemerintahan-Modern-, tanggal 26 Oktober 2014.

Krina, Loina Lalolo. (2003). Indikator dan Alat ukurr Prinsip Akuntabilitas, Transparansi dan Partisipasi: Sekretariat Good Publik governance, BAPPENAS. Jakarta.

Mahmudi (2015), Manajemen Kinerja Sektor Publik Edisi Kedua.Yogyakarta: UPP STIM YKPN.

Mardiasmo. (2006). Perwujudan Transparansi dan Akuntabilitas Publik Melalui Akuntansi SektorPublik: Suatu Saran Good Governance. Jurnal Akuntansi Pemerintahan. Volume 2 Nomor 1. Mei 2006. Hal 2-4.

Mardiasmo. (2010). Akuntansi Sektor Publik. Andi Offset: Yogyakarta.

Miles, M. B \& Huberman. (1992). Analisis Data Kualitatif. Terjemahan oleh Tjetjep Rohendi Rohadi. Jakarta: Universitas Indonesia Press. 
M. Iswahyudi. (2017). Determinan Sikap Pemerintah Desa Dalam Menggunakan Sistem E-village Budgeting. JIAP, 3(2): 90-98.

Pollitt, C., Birchall, J. and Putman, K. (1998), Decentralizing Public Service Management, Macmillan, London.

Prybutok, V. R., Zhang, X. \& Ryan, S. D. (2008). Evaluating leadership, IT quality, and net benefits in an e-government environment. Information \& Management, 45(3): 143-152. Available at: http:// linkinghub.elsevier.com/retrieve/pii/S0378720608000165 [Accessed May 29, 2013]. Yildiz (2007).

Ratih Nur Pratiwi. (2016). Manajemen Keuangan Desa Melalui Inovasi Electronic Village Budgeting (Studi pada Badan Pemberdayaan Masyarakat dan Pemerintahan Desa Kabupaten Banyuwangi). JIAP, 2(3): 123-130.

Shah, A., Riatu Qibthiyyah dan Astrid Dita. (2012). General Purpose Centralprovincial-local Transfers (DAU) in Indonesia. Working Paper.6075. World Bank Policy Research.

Solekhan, M. (2012). Penyelenggaraan Pemerintah Desa Berbasis Partisipasi Masyarakat dalam Membangun Mekanisme Akuntabilitas. Malang: Setara Press.

Sosiawan, Edwi Arief. (2008). Tantangan dan Hambatan dalam Implementasi EGovernment di Indonesia. Paper disajikan pada Seminar Nasional Informatika 2008 (semnasIF 2008), UPN "Veteran" Yogyakarta, 24 Mei 2008. Diakses melalui http://edwi.upnyk.ac.id/Tantangan \%20egov.pdf, pada tanggal 9 Januari 2018.

T. A. Pardo, T. Nam, and G. B. Burke. (2012). E-Government Interoperability Interaction of Policy, Management, and Technology Dimensions. Soc. Sci. Comput. Rev., 30(1): 7-23.

Wang, Y., \& Liao, Y. (2008). Assessing e-Government Systems Success: A Validation of the DeLone and McLean Model of Information System Success. Government Information Quarterly: 717-733.

Undang-Undang (UU) Nomor 23 Tahun 2014 tentang Pemerintah Daerah.

Undang-Undang No. 6 Tahun 2014 Tentang Desa.

Peraturan Menteri Dalam Negeri Nomor 113 Tahun 2014 Tentang Pengelolaan Keuangan Desa.

Peraturan Bupati Banyuwangi No. 15 Tahun 2015 Tentang Pedoman Pengelolaan Keuangan Desa Di Kabupaten Banyuwangi.

Werimon, Simson, Imam Ghozali, \& M. Nasir. (2007). Pengaruh Partisipasi Masyarakat dan Transparansi Kebijakan Publik Terhadap Hubungan Antara Pengetahuan Dewan Tentang Anggaran Dengan Pengawasan Keuangan Daerah (APBD). Makalah disajikan pada Simposium Nasional Akuntansi X Makassar. Hal 21-23.

Wollman, Hellmut. (2007). Devolution of Public Tasks between (Political) Decentralization and (Administrative) Deconcentration-in Comparative (European) Perspective. dalam Social Science Institute of Tokyo University.

World Bank/International Bank for Reconstruction and Development (1999), Entering the 21st Century: World Development Report, 1999/2000, Oxford Press, New York, NY. 
news.detik.com

nasional.sindonews.com

netralnews.com

WwW.jpnn.com

http://e-VillageBudgeting.banyuwangikab.go.id/)

\section{Copyrights}

Copyright for this article is retained by the author(s), with first publication rights granted to the journal.

This is an open-access article distributed under the terms and conditions of the Creative Commons Attribution license (http://creativecommons.org/licenses/by/4.0/). 